\title{
Effect of Profitability, Leverage, Liquidity, Audit Committee on Financial Distress
}

\author{
Rona Tumiur Mauli Carolin Simorangkir ${ }^{*}$ \\ Mercu Buana University Indonesia
}

\begin{abstract}
DOI: 10.36348/sjef.2020.v04i08.001
| Received: 13.07 .2020 | Accepted: 21.07.2020 | Published: 06.08.2020

*Corresponding author: Rona Tumiur Mauli Carolin Simorangkir
\end{abstract}

\section{Abstract}

The purpose of this study is to analyze the effects of Profitability, Leverage, and Liquidity on Financial Distress which is proxied using Z-scores. The object of research is the sub-sector of property and real estate companies listed on the Indonesia Stock Exchange in 2016-2018. This research was conducted using a sample of 47 companies listed on the Indonesia Stock Exchange. Determination of the sample using a purposive sampling method with criteria by researchers using a causal relationship design. The analysis of data use statistical analysis in the form of multiple linear regression tests. The result of this study is that profitability, and liquidity variables have significant effects and positive on financial distress. The Leverage variable has a significant effect and negative on financial distress. While The Audit Committee has no effect on financial distress.

Keywords: Profitability, Leverage, Liquidity and Financial distress.

Copyright @ 2020: This is an open-access article distributed under the terms of the Creative Commons Attribution license which permits unrestricted use, distribution, and reproduction in any medium for non-commercial use (NonCommercial, or CC-BY-NC) provided the original author and source are credited.

\section{INTRODUCTION}

Financial statements are a structured presentation of a company's financial position and financial performance. The purpose of financial statements is to provide information about a financial position, financial performance, and cash flow of the entity useful for some users of financial statements in making decisions. From the financial statements can also show results for accountability for the use of resources that are trusted to the company. The company was founded with the aim of obtaining profits through the business that it runs, in running and falling business is a normal thing that happens by a company. When a company experiences financial difficulties, it becomes a consideration for investors or creditors who will invest their capital. That way a company should be able to show the company's good performance in order to get an injection of funds for the sustainability of the business being run.

According to Fahmi [1], financial distress is a condition in which a company experiences financial difficulties before bankruptcy or liquidation. The financial distress model needs to be developed, because by knowing the company's condition early on, it is expected that actions can be taken to anticipate financial conditions that lead to financial difficulties leading to bankruptcy. Financial distress or company financial problems can be caused by several reasons, such as companies experiencing continuous loss, declining sales, natural disasters that make a company's assets damaged, and can also be caused by an unstable economic condition of a country that triggers a financial crisis to the company.

Profitability is a ratio to assess a company's ability to look for profits or profits in a certain period. The greater the ratio that is produced, the better the company in generating profits for the company so that it is more protected from financial distress Kashmir [2]. Ayu, et al. [3] conducted a study that resulted in profitability and a significant negative effect on financial distress. While the research conducted by Yustika [4] obtained profitability results that had a positive effect on financial distress. Leverage is a ratio used to measure the extent to which a company's assets are financed by debt, the amount of debt used by the company to finance its business activities compared to its own capital [2]. Research conducted by Widhiari and Merkusiwati [5] results in leverage having no effect on financial distress. While research conducted by Kusuma and Sumani [6] results in that leverage has a significant and positive effect on financial distress. According to Kusuma and Sumani [6] liquidity shows the ability of an entity to cover the company's current liabilities by utilizing its current assets. A liquid 
company usually usually has a good performance and will prevent the company from the possibility of financial distress. Nugroho [7] conducted a study that produced liquidity that had no effect on financial distress. While research conducted by Yustika [4] produces liquidity has an influence on financial distress.

\section{REVIEW OF LITERATURE AND HYPOTHESES}

Agency Theory is a theory that explains the conflicts that occur with the company management as an agent with the company owner as the principal. An agency relationship is defined by Jensen and Meckling [8] as a contract between one or more people (principals) who bind another person (agent) to do something on behalf of the principal relating to the delegation of decision-making authority to the agent. In today's economy, management and management of companies are increasingly separated from company ownership. This is in line with Agency Theory which emphasizes the importance of company owners (shareholders) providing company management to professionals who understand more in running the company on a daily basis. The purpose of separating management from company ownership is so that the owner of the company gets the maximum benefit at the most cost-efficient cost as possible by the management of professionals.

Financial Distress is a condition where a company's finances are in an unhealthy state or crisis. Financial distress has a close relationship with bankruptcy in a company, because financial distress is the stage where the company's financial condition decreases before bankruptcy. Financial distress or financial difficulties should be sought to be avoided by all companies, because it can have the worst consequences that could result in a company being declared bankrupt and unable to run a business anymore. Financial distress can be seen when a company has difficulty in fulfilling its obligations to pay its debts to creditors when they are due [4]. Financial distress is influenced by various factors both from internal or external companies. Internal factors that influence financial distress are cash flow difficulties, the amount of the company's debt, and losses experienced by the company in operational activities for several years. While external factors that influence financial distress are more macroeconomic in nature and can have direct or indirect effects, such as an increase in loan interest rates and also natural disasters [3]. Analysis of the Altman Z-score model is an analysis designed to find out predicting financial statements, which is to reveal the strengths and weaknesses of a company to find out whether the financial position is improving or deteriorating for the sake of a company's sustainability, so the $z$ score analysis is more suitable for non-company operating scales. Banks [9]. The Altman model that fits into the property and real estate sub-sector is using
Altman [10] as follows

$\mathrm{Z}=6.56 \mathrm{X}_{1}+3.26 \mathrm{X}_{2}+6.72 \mathrm{X}_{3}+1.05 \mathrm{X}_{4}$

\section{Profitability}

Profitability is the end result of a number of policies and decisions made by the company. If the profitability of the company is good, the creditors, suppliers, and investors will see the extent to which the company can generate profits from the sale and investment of the company [11]. Return on Equity (ROE) is a measurement of earnings (income) available to the owners of the company (both common shareholders and preferred shareholders) on the capital they have invested in the company. In general, of course, the high return or income obtained by the good position of the company owner. Return On Equity or can be called ordinary equity return is a ratio used to measure how much return on ordinary equity. The formula used to find out this ratio is,

$$
\text { ReturnOnEquity }(R O E)=\frac{\text { Lababersih }}{\text { Ekuitas }}
$$

Leverage is a ratio used to measure the extent to which a company's assets are financed with debt, the amount of debt used by the company to finance its business activities compared to its own capital [2]. Companies that have more debt than equity are said to be companies with a high degree of leverage. Leverage can also be used to measure the ratio between total debt to total assets. The leverage ratio is also often referred to as the debt to asset ratio (debt to asset ratio). The leverage ratio describes the extent to which owner's capital can cover debts to outgoing parties. The smaller this ratio, the better, for the security of outsiders the best ratio if the amount of capital is greater than the amount of debt or at least the same. But for shareholders or management this ratio should be large.

$$
\text { Debt to Aset Ratio(DebtRatio })=\frac{\text { TotalHutang }}{\text { TotalAktiva }}
$$

In other words, debt ratio is one type of leverege ratio that measures the amount of company assets financed by debt or capital from creditors. If the ratio calculation results are high then the risk level is also high.

\section{Liquidity}

This ratio shows the ability of an entity to cover the company's current liabilities by utilizing its current assets. A liquid company usually has good performance and will avoid the company from possible financial distress. Liquidity ratios are ratios that illustrate a company's ability to meet its short-term obligations that are due soon [6].

$$
\text { CurrentRatio }(C R)=\frac{\text { AsetLancar }}{\text { KewajibanLancar }}
$$




\section{HYPOTHESIS DEVELOPMENT}

\section{Effect of Profitability on Financial Distress}

In the agency theory, it is explained that there are differences in interests between management and company owners that are prone to conflict. If a company has high profits, management as an agent must also provide social and environmental activities as an embodiment of social contracts that occur in interaction with the community. From the conclusions above, researchers have the opinion that high profitability makes the company experience less financial distress. Yustika's research [4] shows that profitability has an influence on financial distress. This shows the high profitability of a company is able to generate high profits, so that the increase in assets will also occur and will keep the company from the threat of financial distress.

\section{$\mathrm{H}_{1}$ : Profitability affects the financial distress}

\section{Effect of Leverage on Financial Distress}

Leverage is a ratio used to measure the extent to which a company's assets are financed with debt, the amount of debt used by the company to finance its business activities compared to its own capital [2]. Financial distress can be known from the inability of the company to fulfill its obligations, both short-term obligations included in the liquidity category and also included in the solvency category. This is in accordance with research Andre and Taqwa [12] shows that leverage has a significant effect on financial distress. This shows that the greater the amount of debt compared to company assets, the higher the probability of the company experiencing financial distress.

\section{$\mathrm{H}_{2}$ : Leverage affects Financial Distress}

\section{Effect of Liquidity on Financial Distress}

Liquidity shows the ability of an entity to cover the company's current liabilities by utilizing its current assets. Liquid companies usually have good performance and will avoid the possibility of financial distress. High cash and accounts receivable describe the company making high sales, which means high sales can cover existing expenses and can also pay off shortterm debt owned [6]. Yustika's research results [4] show that liquidity has an influence on financial distress. This shows that the lower the liquidity, the more likely the company is experiencing financial distress, because the company is unable to meet its short-term debt.

\section{RESEARCH METHODS \\ Variable Definition and Operations \\ Dependent Variable}

Financial Distress

To measure financial distress using the Altman Z-score. The Altaman model is as follows: $\mathrm{Z}=$ $6.56 X_{1}+3.26 X_{2}+6.72 X_{3}+1.05 X_{4}$

\section{Independent Variable}

a) Profitability

Profitability is a ratio to assess a company's ability to seek profits or profits in a certain period [2].

$$
\text { Return On Equity }=\frac{\text { Net Income }}{\text { Total Equity }}
$$

\section{b) Leverage}

Leverage is a ratio used to measure the extent to which a company's assets are financed with debt, the amount of debt used by the company to finance its business activities compared to its own capital [2].

$$
\text { Debt to Asset Ratio }=\frac{\text { Total Liabilites }}{\text { Toal Asset }}
$$

c) Liquidity

Liquidity ratios are ratios that illustrate a company's ability to meet its short-term obligations that are due soon.

$$
\text { Current Ratio }=\frac{\text { Current Asset }}{\text { Current liabilities }}
$$

\section{Population and Sample}

The population of this sample is the building construction sub-sector company which is listed on the Indonesia Stock Exchange (IDX). The sample is a portion of data taken from the population using certain methods. Sampling in this study by purposive sampling, namely data source sampling techniques with certain considerations [13], the criteria in taking these samples are:

1. Property and real estate sub- sector companies listed on the Indonesia Stock Exchange in the period 2016 to 2018.

2. Property and real estate sub- sector companies listed on the Indonesia Stock Exchange which publishes annual reports for the period of 2016 to 2018.

3. Property and real estate sub- sector companies listed on the Indonesia Stock Exchange that suffered losses in the period of 2016 to 2018 . 
Table-4.7: Sample Selection Criteria

\begin{tabular}{|c|l|c|}
\hline NO & \multicolumn{1}{|c|}{ Information } & total \\
\hline 1 & $\begin{array}{l}\text { Number of property and real estate sub-sector companies listed } \\
\text { on the Indonesia Stock Exchange in 2018 }\end{array}$ & 59 \\
\hline 2 & $\begin{array}{l}\text { Property and real estate sub-sector companies delesting from the } \\
\text { IDX in 2016 to 2018 }\end{array}$ & $(3)$ \\
\hline 3 & $\begin{array}{l}\text { New property and real estate sub sector companies were listed on } \\
\text { the Indonesia Stock Exchange during the period of 2016 to 2018 }\end{array}$ & $(9)$ \\
\hline 4 & Number of Samples & 47 \\
\hline 5 & Research Year & 141 \\
\hline
\end{tabular}

Source: which has been processed?

\section{DATA ANALYSIS METHOD}

\section{a) Descriptive Statistics Analysis}

Descriptive analysis provides a description or description of the data seen from the mean (mean), standard deviation, variance, maximum, minimum, sum, range, kurtosis, and skeness (skewed distribution) [1]. Descriptive statistics are used by research to provide information about the characteristics of variables. The purpose of descriptive statistical analysis in this study was to determine the profitability, leverage, and liquidity of financial distress.

\section{b) Classical Assumption Test Analysis}

The classic assumption test aims to ensure that the data generated are normal distribution. The classic assumption tests used are the Normality Test, the Multicolonierity Test, the Heteroscedasticity Test and the Autocorrelation Test.

\section{c) Test Determinant coefficient $\left(R^{2}\right)$}

Test determinant coefficient $\left(\mathrm{R}^{2}\right)$ was conducted to determine how much interest or closeness of variables, between the dependent variable and independent variables.

\section{d) Simultaneous Significance Test (Statistical Test F)}

This test basically shows whether all independent variables in the regression model have a joint influence on the dependent variable [1]. For the purpose of decision making, a significance level of 0.05 $(5 \%)$ is used.

\section{e) Individual Parameter Significance Test (Statistical Test t)}

This test basically shows how far the influence of one independent variable individually in explaining the variation of the dependent variable. The test was carried out using a significance level of 0.05 ( $\alpha \square=5 \%$ ) [1].

\section{f) Multiple Linear Regression Analysis}

Multiple linear regressions are a measure of the effect between the dependent variable and the dependent variable (Y) with two or more independent variables $(\mathrm{X})$. So that a variable can be predicted from other variables. The form of the equation in this study is:

$$
\mathrm{FD}=a+\beta 1 \mathrm{ROE}+\beta 2 \mathrm{DAR}+\beta 3 \mathrm{CR}+\beta 4 \mathrm{KA}+e
$$

\section{Information}

FD = Financial Distress

$\mathrm{ROE}=$ Return on equity

$\mathrm{DAR}=$ Debt to assets ratio

$\mathrm{CR}=$ Current Ratio

$\mathrm{KA}=$ Audit Committee

$a=$ Constant

$\beta 1-5=$ Regression Coefficient

$e=$ Error

\section{RESULTS AND TRANSLATIONS}

\section{The coefficient of determination results}

The results of the determinant coefficient test in table 4.7 above can be seen that the $R$ Square value of 0.408 shows that the variation of financial distress can be explained by variations in profitability, leverage, liquidity of $40.8 \%$. While the remaining $59.2 \%$ (100\% $40.8 \%$ ) is influenced by other factors not examined.

\section{Tatistical Test $\mathbf{F}$}

Table-4.8: Simultaneous Significance Test Results (Test F)

\begin{tabular}{|l|l|r|r|r|r|c|}
\hline \multicolumn{7}{|l|}{ ANOVA } \\
\hline \multicolumn{2}{|l|}{ Model } & Sum of Squares & \multicolumn{1}{c|}{ df } & Mean Square & F & Sig. \\
\hline \multirow{3}{*}{1} & Regression & 293,666 & 4 & 73,416 & 18,111 & $.000^{\mathrm{b}}$ \\
\cline { 2 - 7 } & Residual & 381,040 & 94 & 4,054 & & \\
\cline { 2 - 7 } & Total & 674,706 & 98 & & & \\
\hline \multicolumn{2}{|l}{ a. Dependent Variable: Y } \\
\hline
\end{tabular}


Based on the Simultaneous Significance test (Test F) in table 4.8 above it is known that the $\mathrm{F}$ value of 24.578 with a probability of $0.000<0.05$, this means that the model is feasible to be used in this study. So it can be concluded that profitability, leverage, liquidity simultaneously significantly affect financial distress.

Table-4.9: Significance Test Results for Individual Parameters (Statistical Test t)

\begin{tabular}{|c|c|c|c|c|c|c|}
\hline \multicolumn{7}{|c|}{ Coefficients a } \\
\hline \multirow{2}{*}{\multicolumn{2}{|c|}{ Model }} & \multicolumn{2}{|c|}{ Unstandardized Coefficients } & \multirow{3}{*}{$\begin{array}{c}\text { Standardized Coefficients } \\
\text { Beta } \\
\end{array}$} & \multirow{3}{*}{$\begin{array}{c}\mathbf{t} \\
5,405 \\
\end{array}$} & \multirow{3}{*}{$\begin{array}{l}\text { Sig. } \\
.000 \\
\end{array}$} \\
\hline & & $\mathrm{B}$ & Std. Error & & & \\
\hline \multirow[t]{5}{*}{1} & (Constant) & 3,833 & 709 & & & \\
\hline & $\mathrm{X} 1$ & 13,247 & 2,693 & .383 & 4,918 & .000 \\
\hline & $\mathrm{X} 2$ & $-3,921$ & 1,323 & -.266 & $-2,964$ & .004 \\
\hline & $\mathrm{X} 3$ & .462 & 109 & .358 & 4,246 & .000 \\
\hline & $\mathrm{x} 4$ & -241 & 279 & -.072 & -.864 & .390 \\
\hline
\end{tabular}

\section{The data source isprocessed by SPSS20}

Based on the results of the t test in table 4.9 above we can get the multiple linear regression equation as follows:

$\mathrm{FD}=3,833+13,247 \mathrm{ROE}-3,921 \mathrm{DAR}+0,462 \mathrm{CR}-$ $0,241 \mathrm{KA}+e$

\section{Effect of Profitability on Financial Distress}

The first hypothesis states that there is an effect of profitability on financial distress. The results showed that 0.000 was obtained which was smaller than the significance of 0.05 ( $\mathrm{sig} 0,000<0.05)$ so that proving profitability had a significant positive effect on financial distress. These shows that every $1 \%$ increase in ROE will also increase the company avoid financial distress of $13,247(13,247 \%)$. That if the percentage of profitability is high, it can be interpreted that the greater the company will avoid financial distress. If the level of profitability is high, it will attract investors to invest their capital because they have good company value and make the company avoid financial distress.

The results of this study are in line with that conducted by Listyorini wahyu widati [14] using the Return on Equity (ROE) proxy which states that profitability has a significant positive effect on financial distress.

\section{Effect of Leverage against Financial Distress}

The Second Hypothesis states that there is an influence of leverage on financial distress. Hypothesis research results obtained by 0.004 which is smaller than the significance of $0.05(0.004<0.05)$, thus proving that leverage has a significant negative effect on financial distress. Leverage regression coefficient of -3.921 , this shows that every $1 \%$ increase in leverage will cause a decrease in financial distress by the coefficient and vice versa.

The results showed that the leverage variable with a debt ratio proxy had a negative effect on financial distress. That is, a lot of the company's assets financed by debt. The use of debt that is too high will endanger the condition of a company. When a company has a lot of debt to be used as capital, it is feared that the obligations borne by the company have a high value, resulting in a high leverage ratio. So with a negative leverage value, it means that the amount of debt accumulated against the company's capital is greater and is prone to meeting its long-term obligations. It could be said also in subsectors of the property and real es tate more to finance its operations by using capital obtained from third parties in the form of debt. A large company tends to rely mostly on financing on bank loans. It can be concluded that the use of debt in this sector affects financial distress. If a company does not use its assets that are financed with debt optimally and on target, it causes the company to suffer losses. Art Inya if companies manage debt properly make the company can avoid the occurrence of financial distress.

This study is in line with research conducted by Sakinah [15] which uses a debt to ratio (DAR) proxy with the results of leverage having $a$ negative effect on financial distress.

\section{Effect of Liquidity on Financial Distress}

The third hypothesis states that there is an influence of liquidity on financial distress. The results showed a value of 0,000 which was smaller than 0.05 $(\operatorname{sig} 0,000<0.05)$, this proves that every $1 \%$ increase in the current ratio then there was an increase in financial distress by $0.462(0.462 \%)$ which means that the company is more likely to meet obligations the short term by relying on current assets. This proves that liquidity has a significant positive effect on financial distress.

Liquidity ratios in a company should be one of the pillars of the company in order to survive in the face of the possibility of financial distress. Liquidity difficulties can be caused by the company's failure to collect receivables from customers or other parties. The impact of the failure of collection of receivables is what causes the company does not have sufficient funds to 
pay for its obligations and operational needs of the company.

The results of this study are consistent with the results of research conducted by Kusuma and Sumani [6], as well as Yudiawati and Indriani [16], which prove that liquidity has a positive influence on financial distress. Similar with Anggraini [17], Current Ratio has positive influence on Financial Distress.

\section{Effect of audit committee on financial distress}

The Audit Committee has a significance probability of 0.864 . This shows that the probability of significance is greater than the significance level $\alpha=$ $0.05(0,394>0.05)$. So this partially variable Audit Committee has no influence on financial distress.

This means that the audit committee as measured by the intensity of the audit committee meeting cannot reflect the company in the healthy category, because in the audit committee meeting is not only intended to discuss financial distress but the survival of the company.

The results of this study are consistent with the results of Damayanti [18] research which proves that the Audit Committee has no effect on Financial Distress. This proves the results of this study are consistent that the Audit Committee has no influence on Financial Distress.

The occurrence of financial distress. Liquidity difficulties can be caused by the company's failure to collect receivables from customers or other parties. The impact of the failure of the collection of receivables is what causes the company does not have sufficient funds to pay for its obligations and operational needs of the company. The results of this study are consistent with the results of research conducted by Kusuma and Sumani [6], as well as Yudiawati and Indriani [16], which proves that liquidity positive effect on financial distress.

\section{CONCLUSION}

From the results of research conducted by the author, the following conclusions can be drawn:

1. Profitability that uses the Return On Equity (ROE) proxy has a positive effect on financial distress and this ratio can predict the condition of financial distress in the property and real estate sub sector listed on the Indonesian stock exchange

2. Leverage using the Debt to Asset Ratio (DAR) proxy has a negative effect on financial distress in the property and real estate sub-sector.

3. Liquidity using the current ratio $(\mathrm{CR})$ proxy has a positive effect on financial distress in the property and real estate sub-sector.
4. Audit committee has negative effect on financial distress in the property and real estate sub sector.

\section{SUGGESTION}

Based on the results of the discussion and conclusion above, the writer tries to give the following advice

1. Academics can conduct research using other variables or add other variables as independent variables. Considering there are many other factors that can affect financial distress.

2. The company must pay more attention to the performance and ability of the company in managing their assets so as to avoid the possibility of financial distress or bankruptcy of the company. The company must also conduct a review of the company's debt in an effort to avoid the occurrence of a default moment, one of which is the cause of the potential financial distress.

3. For investors, the results of this study can be taken into consideration by observing the financial performance produced by the company. From these observations investors will get complete information so they can choose companies that have good performance so as not to lose in investing their capital in a company.

4. It is hoped that this research can provide an overview of accounting practices carried out in the business world, and can be additional information and references for further research on the topic under study. This research can add and increase knowledge and insight about accounting knowledge related to factors that can affect financial distress.

\section{REFFERENCE}

1. Imam, G. (2016). "Multivarite Analysis Application with SPSS Program".

2. Kasmir. (2014). Banks and Other Financial Institutions. Revised Edition, Prints to Fourteen, PT. Raja Grafindo Persada, and Jakarta.

3. Ayu, A.S., \& Handayani, S. R. (2017). The Effect of Liquidity, Leverage, Profitability, and Company Size on Financial Distress Studies in Manufacturing Companies of Basic and Chemical Industrial Sectors Listed on the Indonesia Stock Exchange in 2012-2015. Journal of Business Administration, 43(1), 138-147.

4. Yustika, Y., \& Silfi, A. (2016). Effect of Liquidity, Leverage, Profitability, Operating Capacity and Managerial Agency Costs on Financial Distress (Empirical Study of Manufacturing Companies Listed on the Indonesia Stock Exchange in 20112013). Online Student Journal (JOM) in Economics, 2(2), 1-15.

5. Widhiari, N. L. M. A., \& Merkusiwati, N. K. L. A. (2015). Pengaruh rasio likuiditas, leverage, operating capacity, dan sales growth terhadap financial distress. E-Jurnal Akuntansi Universitas Udayana, 11(2), 456-469. 
6. Kusuma, E., \& Sumani, S. (2017). Effect of Liquidity, Leverage and Profitability on Financial Distress (Z-Score) of Property, Real Estate, and Manufacturing Companies. Journal of Management, 14 (1), 1-16.

7. Nugroho, A.A., Baridwan, Z., \& Mardiati, E. (2018). The Effect of Profitability, Liquidity, Leverage, and Corpo-Rate Governance on Fraudulent Financial Statements, and Financial Distress as Intervening Variables. Media Trend, 13 (2), 219-240.

8. Jensen, M. (1976). Meckling. 1976. Theory of the Firm: Managerial Behaviour, Agency Costs, and Ownership Structure, 22.

9. Darsono., \& Ashari. (2010). Practical Guidelines for Understanding Financial Statements. Jakarta Salemba Empat. Seventh edition. Diponegoro University publishing body, Semarang.

10. Altman, R. D., Hochberg, M., Murphy Jr, W. A., Wolfe, F., \& Lequesne, M. (1995). Atlas of individual radiographic features in osteoarthritis. Osteoarthritis and cartilage, 3(SUPPL. A), 3-70.

11. Brigham, E. F., \& Houston, J. F. (2012). Fundamentals of financial management. Cengage Learning.

12. Andre, O., \& Taqwa, S. (2014). Effect of Profitability, Liquidity, and Leverage in Predicting
Financial Distress (Empirical Study of Various Industrial Companies Listed on the Indonesia Stock Exchange 2006-2010). Forum for Accounting Research, 2 (1).

13. Sugiyono, P. D. (2013). Metode penelitian manajemen. Bandung: Alfabeta, $C V$.

14. Widati, L.W. (2015). Effect of current ratio, debt to equity ratio, and return on equity, to predict financial distress.

15. Jarial, R., Thakur, S., Sakinah, M., Zularisam, A. W., Sharad, A., Kanwar, S. S., \& Singh, L. (2018). Potent anticancer, antioxidant and antibacterial activities of isolated flavonoids from Asplenium nidus. Journal of King Saud UniversityScience, 30(2), 185-192.

16. Nahdi, H. M. (2013, November). Pengaruh Current Ratio, Debt To Total Asset Ratio, Total Asset Turnover (TATO), Beban Operasional Pendapatan operasional (BOPO), Dan Dana Pihak Ketiga (DPK) Terhadap Profitabilitas Bank Umum Syariah. In Performance (Vol. 17, No. 1).

17. Dewi, A., \& Hadri, M. (2017). Financial distress prediction in Indonesia companies: finding an alternative model. Russian Journal of Agricultural and Socio-Economic Sciences, 61(1).

18. Damayanti, M., Scott, N., \& Ruhanen, L. (2017). Coopetitive behaviours in an informal tourism economy. Annals of Tourism Research, 65, 25-35. 